\title{
PERAN CITRA DESTINASI, E-WOM, DAN TRAVEL CONSTRAINTS PADA NIAT BERKUNJUNG WISATA PANTAI DI KOTA SURABAYA, JAWA TIMUR
}

\author{
Novita Eka Indriyani \\ Fakultas Ekonomi Universitas Negeri Surabaya \\ Email: novitaindriyani16080574067@mhs.unesa.ac.id \\ Yessy Artanti \\ Fakultas Ekonomi Universitas Negeri Surabaya \\ Email: yessyartanti@unesa.ac.id
}

\begin{abstract}
ABSTRAK
Kawasan Pantai Kenjeran merupakan wisata alam yang berupa pantai di dekat pusat Kota Surabaya. Pantai Kenjeran telah lama dibuka untuk umum dan melakukan berbagai pengembangan destinasi wisata, namun jumlah pengunjung wisata Pantai Kenjeran mengalami penurunan. Penelitian ini bertujuan untuk menganalisis dan membahas pengaruh citra destinasi, $e$-WOM, dan travel constraints terhadap niat berkunjung calon pengunjung Pantai Kenjeran Kota Surabaya. Penelitian ini menggunakan metode kuantitatif. Sampel berjumlah 200 responden dengan teknik nonprobability sampling dan metode yang digunakan adalah judgmental sampling. Data diolah menggunakan analisis regresi linier berganda. Hasil penelitian menunjukkan adanya pengaruh positif pada variabel citra destinasi terhadap niat berkunjung, kemudian variabel $e$-WOM tidak berpengaruh terhadap niat berkunjung calon pengunjung, serta variabel travel constraints berpengaruh negatif terhadap niat berkunjung ke Pantai Kenjeran.
\end{abstract}

Kata kunci: Citra destinasi, e-WOM, travel constraints, niat berkunjung. 


\section{PENDAHULUAN}

Industri pariwisata merupakan salah satu sektor yang memberikan pengaruh penting dalam kemajuan ekonomi suatu negara seperti halnya Indonesia. Hal tersebut dapat dilihat bahwa kini kegiatan wisata telah menjadi tren dan kebutuhan bagi masyarakat di segala kalangan dan usia. Menurut Kementerian Kebudayaan dan Pariwisata, pendapatan devisa Indonesia yang didapatkan dari sektor pariwisata sejak tahun 2009 hingga tahun 2019 menunjukkan adanya peningkatan secara signifikan. Pada tahun 2019 penerimaan devisa pariwisata mencapai 17,6 miliar US\$, penerimaan tersebut mengalami kenaikan sebesar 1,5 miliar US\$ dibanding dengan tahun 2018 dengan penerimaan devisa pariwisata sebesar 16,1 miliar US\$. Pengembangan potensi pariwisata dilaksanakan di setiap daerah yang ada di Indonesia dengan mengoptimalkan destinasi wisata yang ada serta menggali potensi wisata baru yang dapat dikembangkan menjadi sebuah destinasi baru. Tentu saja hal tersebut membutuhkan kerjasama antara pemerintah hingga masyarakat agar pengembangan pariwisata dapat berjalan dengan optimal dan dapat menumbuhkan niat bagi wisatawan untuk berkunjung. Niat berkunjung seseorang dapat dipengaruhi oleh beberapa faktor salah satunya adalah citra destinasi yang melekat pada sebuah obyek wisata. Utama (2017:219) menjelaskan teorinya bahwa dalam dunia pariwisata, pada hakikatnya citra dapat menggerakkan dan mendorong wisatawan untuk menentukan pilihan destinasi wisatanya. Menurut Crompton (1979:18; dalam Chaulagain et al., 2019) menyebutkan citra destinasi mengacu pada sejumlah kesan, kepercayaan, pikiran, persepsi, dan perasaan yang dibangun dari waktu ke waktu menuju suatu tempat. Selanjutnya citra destinasi mempunyai arti sebagai representasi mental individu tentang pengetahuan, perasaan, dan kesan global tentang suatu tujuan (Pratt \& Sparks, 2014).

Perkembangan teknologi yang semakin pesat membuat masyarakat lebih mudah dalam mencari informasi guna menentukan destinasi wisata apa saja yang ingin dikunjungi, masyarakat akan melakukan pencarian informasi berupa akses perjalanan untuk mencapai tujuan wisata, fasilitas yang ada, hingga ulasan dari beberapa orang yang telah lebih dahulu mengunjungi wisata tersebut dan seringkali membagikan pengalamannya. Beberapa hal penting tersebut sangat berpengaruh terhadap pembentukan sikap bagi masyarakat akankah harus mengunjungi destinasi tersebut atau tidak. Sebelum berkunjung ke sebuah tempat wisata, biasanya orang akan mencari tahu mengenai pendapat orang lain yang telah mengunjungi tempat tersebut untuk mendukung kepada perilaku apa yang akan diambil setelahnya, apakah akan berkunjung atau tidak. e-WOM sangat memengaruhi keputusan 
konsumen atau wisatawan, karena calon wisatawan menganggap $e$-WOM memuat informasi terbaru, menyenangkan, dan lebih dapat diandalkan daripada informasi yang disediakan oleh penyedia jasa pariwisata (Abubakar \& Ilkan, 2016). Sebelum seseorang memutuskan untuk mengunjungi sebuah wisata, terdapat beberapa faktor yang menjadi pertimbangan untuk memutuskan berwisata. Menurut Jackson (1988; dalam Edward \& Balqiah, 2014) terdapat dua faktor yang dapat membentuk niat berkunjung pada seorang individu, yaitu manfaat (benefit) dan hambatan (constraints).

Obyek wisata dapat meliputi wisata alam, wisata budaya dan wisata buatan yang banyak diminati oleh wisatawan. Dari objek-objek wisata yang menjadi destinasi wisata unggulan di Provinsi Jawa Timur, terdapat beberapa destinasi wisata yang menjadi prioritas untuk dikembangkan, salah satunya adalah Kota Surabaya dengan destinasi wisata Pantai Kenjeran. Destinasi wisata Pantai Kenjeran termasuk dalam program prioritas pengembangan destinasi pariwisata pada laporan rencana strategis Dinas Kebudayaan dan Pariwisata Jawa Timur tahun 2019 - 2024. Pantai Kenjeran dikembangkan sebagai wisata alam di Kota Surabaya.

Kawasan Pantai Kenjeran dibagi menjadi dua area wisata yaitu kawasan Taman Hiburan Pantai (THP) Kenjeran dan kawasan Kenjeran Park. THP Kenjeran berada di Kelurahan Kenjeran, Kecamatan Bulak yang berdiri pada tahun 1968 dengan luas \pm 4,3 Ha. Sedangkan di kawasan Kenjeran Park, kegiatan yang dapat dilakukan wisatawan lebih kepada wisata konvensional. Sedangkan Kenjeran Park berlokasi di Jl. Sukolilo, Kelurahan Sukolilo baru, Kecamatan Bulak, Kota Surabaya. Lokasi dari kawasan Kenjeran Park tidak jauh dengan lokasi THP Kenjeran sehingga masih dalam satu kawasan. Kenjeran Park mulai dibuka untuk umum sejak tahun 1947.

Pantai Kenjeran sebagai wisata yang telah lama ada di Kota Surabaya telah melakukan berbagai pengembangan produk wisatanya dengan baik, serta melakukan promosi sebagai upaya pengenalan wisata kepada wisatawan nusantara dan mancanegara (kemenparekraf.go.id). Pengembangan produk wisata penting dilakukan agar wisatawan tidak merasa jenuh saat berkunjung. Pengelola wisata Pantai Kenjeran juga harus menjaga citra baik wisatanya karena citra dari produk wisata yang terkait dengan destinasi wisata dan fasilitas pariwisata, secara langsung dapat memenuhi kebutuhan wisatawan (Zhang et al., 2017). Dahulu kawasan Pantai Kenjeran merupakan kawasan pantai yang kumuh dan tidak layak dijadikan sebagai obyek wisata karena selain kumuh, kawasan Pantai Kenjeran juga menjadi tempat yang rawan terjadi tindak kriminalitas (nativeindonesia.com, 2019). Namun 
untuk dapat bertahan pada industri pariwisata hingga saat ini, wisata Pantai Kenjeran melakukan berbagai pengembangan pariwisatanya serta berusaha untuk memperbaiki citra destinasi wisata Pantai Kenjeran dengan cara lebih memperhatikan kebersihan pantai, peningkatan fasilitas serta memperketat keamanan di area wisata Pantai Kenjeran dengan memberikan CCTV serta lampu penerangan yang cukup (surabaya.go.id).

Beberapa sektor pendukung pariwisata juga telah dibangun, seperti dibangunnya Sentra Ikan Bulak pada bulan Desember 2012 sebagai pusat pengolahan dan pemasaran hasil olahan laut bagi nelayan di Surabaya kemudian dibangunnya Jembatan Suroboyo dan diresmikan pada tanggal 9 Juli 2016 untuk menambah destinasi wisata baru dan cara baru menikmati pemandangan Pantai Kenjeran dari sisi yang berbeda, serta diresmikannya Taman Bulak pada tanggal 29 Mei 2019 yang menjadi land mark baru di Kota Surabaya Utara. Sehingga diharapkan dapat menambah niat kunjungan wisatawan mengunjungi kawasan Pantai Kenjeran di Kota Surabaya.

Berikut terdapat data berupa jumlah pengunjung wisatawan nusantara yang datang mengunjungi Pantai Kenjeran tahun 2014 hingga tahun 2018.

\section{Tabel 1}

Data Pengunjung Kawasan Pantai Kenjeran Pada Tahun 2014 - 2018

\begin{tabular}{ccc}
\hline Tahun & THP Kenjeran & Kenjeran Park \\
\hline 2014 & 670.271 & 438.295 \\
2015 & 715.690 & 492.858 \\
2016 & 747.950 & 548.874 \\
2017 & 950.195 & 511.089 \\
2018 & 583.275 & 408.802 \\
\hline
\end{tabular}

Sumber : Dinas Kebudayaan dan Pariwisata Provinsi Jawa Timur (diolah pada Januari 2020)

Data pengunjung yang tersaji dalam tabel 1 menunjukkan bahwa pada tahun 2014 hingga 2017 terdapat peningkatan jumlah pengunjung kawasan wisata Pantai Kenjeran. Namun di tahun 2018 terjadi penurunan jumlah pengunjung kawasan wisata Pantai Kenjeran (THP Kenjeran dan Kenjeran Park). Meskipun wisata Pantai Kenjeran telah lama diresmikan di Kota Surabaya dan menjadi wisata pantai satu-satunya, serta pengelola wisata telah melakukan pengembangan agar menarik wisatawan untuk berkunjung dengan meningkatkan citra destinasi wisata dan gencar melakukan promosi sebagai pengenalan wisata Pantai Kenjeran ke wisatawan nusantara, tetapi masih terjadi penurunan jumlah pengunjung wisata Pantai Kenjeran. Dari penjelasan fenomena yang terjadi serta beberapa hasil penelitian terdahulu yang mendukung, hal tersebut mendasari peneliti untuk mengetahui bagaimana citra destinasi, e-WOM, dan travel constraints dapat mempengaruhi niat berkunjung 
seseorang dengan studi yang dilakukan pada wisata Pantai Kenjeran di Kota Surabaya.

\section{TELAAH PUSTAKA}

\section{Niat Berkunjung}

Kata niat dapat didefinisikan menjadi sebuah ketertarikan (interest) yang dirasakan oleh seorang individu terhadap suatu hal. Dalam bidang pemasaran pariwisata, definisi niat dapat diartikan menjadi ketertarikan yang dapat dirasakan oleh wisatawan terhadap suatu tempat wisata yang memiliki daya tarik tertentu (Cahyanti \& Anjaningrum, 2018). Dalam penelitian Chen et al., (2014), niat berkunjung disebutkan sebagai kemauan untuk mengunjungi suatu destinasi wisata. Niat berkunjung mengacu pada probabilitas apa yang dirasakan wisatawan selama waktu tertentu sehingga dapat membangun persepsi subyektif yang mempengaruhi perilaku dan keputusan akhir untuk berkunjung (Whang et al., 2016). Niat berkunjung juga berarti kegiatan melakukan atau tidak melakukan suatu perjalanan ke tempat wisata yang telah dipilih melalui informasi yang didapat (Winarta, 2017). Berdasarkan beberapa definisi di atas maka peneliti menyimpulkan bahwa niat berkunjung adalah apa yang dirasakan oleh seseorang yang didukung oleh beberapa faktor seperti adanya kebutuhan, informasi yang mendukung dan persepsi yang dapat mempengaruhi tindakannya untuk mengunjungi suatu destinasi wisata atau tidak. Menurut Ariana dan Sudiarta (2006; dalam Satyarini dkk, 2017) terdapat tiga faktor yang dapat membentuk atau mempengaruhi seseorang untuk berkunjung pada suatu destinasi wisata yaitu, (1) Keinginan untuk mengunjungi tempat atau destinasi wisata berdasarkan informasi yang diperoleh dari media massa; (2) Keinginan untuk mengunjungi tempat atau destinasi wisata berdasarkan kisah yang bersumber dari keluarga dan kerabat; (3) Keinginan untuk mengunjungi tempat atau destinasi wisata karena adanya rasa ingin tahu atau penasaran mengenai suatu tempat atau destinasi wisata.

\section{Citra Destinasi}

Menurut Hidayah (2019:56-57) citra destinasi yang dipersepsikan oleh pengunjung dapat mempengaruhi seseorang dalam memutuskan untuk berkunjung pada destinasi tersebut. Kemudian menurut Chi et al., (2018) definisi dari citra destinasi adalah kumpulan koneksi yang terkait dengan suatu destinasi di benak konsumen. Sedangkan citra destinasi menurut Crompton (1979; dalam Yang et al., 2009) adalah sejumlah kesan, kepercayaan, pikiran, persepsi, dan perasaan yang dibangun dari waktu ke waktu menuju suatu tempat. Berdasarkan 
pengertian tersebut maka dapat disimpulkan bahwa definisi dari citra destinasi wisata adalah sebuah kepercayaan, persepsi, kesan, dan perasaan seseorang mengenai suatu tempat wisata.

Citra destinasi adalah sesuatu yang kompleks untuk menerangkannya dalam dimensi analitis. Citra destinasi menjadi kompleks karena masih banyaknya perdebatan terhadap cara pengukurannya, dan banyaknya komponen yang disertakan dalam pengukuran (Utama, 2017:221). Multi dimensinya citra destinasi disebabkan oleh atribut yang disertakan cukup beragam dan saling terkait (Utama, 2017:222). Citra destinasi wisata didefinisikan sebagai citra dari produk wisata yang terkait dengan destinasi wisata dan fasilitas pariwisata, yang secara langsung dapat memenuhi kebutuhan wisatawan (Zhang et al., 2017). Menurut teori dari Utama (2017:219) dalam dunia pariwisata, citra dapat menggerakkan dan mendorong wisatawan untuk menentukan pilihan destinasi wisatanya. Penelitian yang dilakukan Chaulagain et al., (2019) menunjukkan bahwa citra destinasi berpengaruh positif terhadap niat berkunjung. Hal tersebut didukung dengan penelitian yang dilakukan (Chi et al., 2018) yang mengatakan bahwa citra destinasi memiliki hubungan yang signifikan positif dengan niat perjalanan.

\section{e-WOM (Word of Mouth)}

Perilaku pengunjung pariwisata dapat dipengaruhi oleh beberapa faktor salah satunya adalah aktivitas pemasaran yang dilakukan oleh suatu destinasi wisata. Aktivitas pemasaran yang dilakukan agar masyarakat mengetahui informasi mengenai destinasi wisata dapat dilakukan dengan memilih bauran promosi yang tepat (Hidayah, 2019:56). Adapun menurut Lupiyoadi (2013:97) mengenai informasi dari mulut ke mulut (word of mouth) adalah peranan orang yang sangat penting dalam mempromosikan jasa. Pelanggan sangat dekat dengan penyampaian jasa. Dengan kata lain, pelanggan tersebut akan berbicara kepada pelanggan lain yang berpotensial tentang pengalamannya dalam menerima jasa tersebut sehingga informasi dari mulut ke mulut (word of mouth) ini sangat besar pengaruh dan dampaknya terhadap pemasaran jasa dibandingkan aktivitas komunikasi lainnya.

Word of Mouth (WOM) juga berarti sebuah percakapan yang di desain secara online maupun offline memiliki multiple effect, non-hiearchi, horizontal dan multasional Hasan (2010:29). Percakapan online dapat disebut juga dengan $e$-WOM. Terjadinya $e$-WOM tidak lepas dari pengalaman konsumen atas produk atau jasa yang dikonsumsi. Jika konsumen memperoleh kepuasan dari pengalaman konsumsinya, maka konsumen secara sukarela akan membuat pernyataan (review) mengenai sebuah produk atau jasa tersebut. Menurut Jalilvand 
et al., (2012), informasi atau pesan yang yang terkandung dalam e-WOM dapat menjadi referensi bagi konsumen dalam mengevaluasi sebuah produk atau merek. Menurut Gustiani, (2018) $e$-WOM merupakan komunikasi pemasaran yang berbasis online melalui media sosial internet yang memiliki pesan berisi tentang pernyataan positif atau negatif yang dilakukan oleh konsumen potensial atau konsumen terdahulu. $e-W O M$ sangat memengaruhi keputusan konsumen atau wisatawan, karena calon wisatawan menganggap $e$-WOM memuat informasi terbaru, menyenangkan, dan lebih dapat diandalkan daripada informasi yang disediakan oleh perusahaan wisata (Abubakar \& Ilkan, 2016).

Terdapat beberapa kelebihan ketika sebuah pemasar menggunakan media promosi berupa $e$-WOM yaitu cara promosinya menjadi jauh lebih efektif dibandingkan melalui iklan cetak atau televisi. Menurut Hasan (2010:39) terdapat beberapa kelebihan dari cara promosi menggunakan $e-W O M$ dibandingkan menggunakan iklan konvensional yaitu, (1) bentuk iklan konvensional memerlukan biaya yang besar dibandingkan $e$-WOM; (2) banyak pengalaman konsumen yang menunjukkan bahwa mereka merasa ditipu oleh iklan produk melalui televisi; (3) orang lebih cenderung mempercayai pendapat orang lain yang sudah memiliki pengalaman dalam menggunakan produk; (4) dengan dukungan teknologi informasi berbasis komputer, pemasar dapat melipat gandakan penyebaran informasi (meluas) dalam waktu yang bersamaan; (5) penggunaan ponsel dalam waktu yang singkat membuat informasi dapat menyebar ke banyak orang. Beberapa penelitian menunjukkan bahwa $e-W O M$ secara signifikan dapat memengaruhi niat berkunjung (Albarq, 2013; Jalilvand, 2017; Doosti et al., 2016; Prayogo dkk, 2017). Namun pada penelitian Abubakar, (2016) menunjukkan bahwa terdapat pengaruh yang negatif antara $e-W O M$ dan niat perjalanan.

\section{Travel Constraints}

Keputusan dan tindakan seseorang dalam melakukan kegiatan pariwisata merupakan bentuk aktivitas psikologis saat individu, dan biasanya dipengaruhi oleh berbagai aspek seperti minat kepribadian, hobi, profesi, sikap terhadap kehidupan, persepsi pemahaman terhadap lingkungan sekitar, dan lain-lain. Adapun menurut Crompton (1977; dalam Li et al., 2011) menyebutkan terdapat beberapa faktor seperti kurangnya uang, waktu, minat dan dukungan dari keluarga atau kerabat, serta kesehatan yang buruk adalah kendala utama yang dirasakan dapat mempengaruhi keputusan seseorang untuk melakukan perjalanan. Kemudian menurut Jackson (1988; dalam Edward \& Balqiah, 2014) terdapat dua faktor yang dapat membentuk niat berkunjung pada seorang individu, yaitu hambatan (constraints) dan manfaat 
(benefit). Manfaat sering menjadi faktor penting bagi seseorang dalam berperilaku pada kegiatan wisatanya namun hambatan menjadi faktor penentu yang penting untuk dipertimbangkan bagi calon wisatawan. Hambatan (constraints) sering terjadi ketika seseorang akan mengunjungi sebuah wisata yang belum pernah dikunjunginya. Travel constraints memiliki definisi yang berbeda dengan risk (risiko). Menurut Khan et al., (2019) risiko (risk) didefinisikan sebagai suatu ketidakpastian dan konsekuensi negatif dari pembelian produk atau layanan. Maka dari itu risiko merupakan akibat dari suatu tindakan sedangkan travel constraints (hambatan perjalanan) merupakan sebab seseorang dapat membatalkan niat pembelian atau berkunjung ke suatu objek wisata.

Menurut penelitian yang dilakukan oleh Li et al., (2011) membagi menjadi tiga jenis manfaat dan penghambat yang dapat dirasakan berdasarkan proses pilihan destinasi wisata mereka, yaitu (a) Kebutuhan kepuasan merupakan kebutuhan akan kepuasan menggabungkan serangkaian motivasi seseorang untuk bepergian seperti adanya kebaruan, tantangan, relaksasi, pembelajaran, dan rasa ingin tahu terhadap destinasi wisata; (b) Kesepakatan sosial mencerminkan kecenderungan calon wisatawan untuk bertindak sesuai dengan pendapat dari kelompok sosial mereka; (c) Kemampuan perjalanan menggambarkan kecenderungan seseorang untuk bepergian ke suatu tempat yang dipengaruhi beberapa faktor seperti uang, waktu, keterampilan, dan kesehatan.

Travel constraints (hambatan perjalanan) didefinisikan sebagai faktor yang dapat menghambat partisipasi dan kenikmatan dalam kegiatan rekreasi serta dapat mencegah seseorang bepergian (Hung \& Petrick, 2012). Sedangkan menurut Li et al., (2011) mengartikan travel constraints merujuk pada faktor-faktor yang menghambat perjalanan yang berkelanjutan, yang dapat menyebabkan ketidakmampuan calon pengunjung untuk memulai perjalanan, sehingga mengakibatkan ketidakmampuan untuk mempertahankan atau meningkatkan frekuensi perjalanan, dan/atau menyebabkan efek negatif pada kualitas perjalanan. Pada penelitian yang dilakukan Khan et al., (2016) juga menjelaskan bahwa travel constraints didefinisikan sebagai faktor yang menghambat perjalanan awal atau selanjutnya, menghambat kemampuan seseorang untuk mempertahankan atau meningkatkan frekuensi perjalanan dan/ atau secara negatif dapat mempengaruhi kualitas perjalanan mereka. Meskipun kendala perjalanan dapat menyebabkan seseorang mengurungkan niatnya untuk berkunjung ke destinasi wisata, namun kendala perjalanan masih dapat diatasi dengan melakukan negosiasi dengan apa yang membuat kendala tersebut dapat terjadi. Berdasarkan pengertian tersebut maka dapat disimpulkan bahwa definisi dari travel constraints adalah 
faktor yang dapat mencegah seseorang memulai niatnya untuk berwisata atau berkunjung ke destinasi wisata.

Menurut Khan et al., (2019) travel constraints memiliki arti sebagai variabel dan menjelaskan mengenai hambatan yang dapat timbul seperti waktu, uang, peluang, pengetahuan, kemampuan, kepadatan penduduk, kurangnya pasangan, rasa malu, kurangnya transportasi, keselamatan, minat dan kualitas buruk yang dapat mencegah seseorang dalam kegiatan berwisata. Berdasarkan penelitian yang dilakukan oleh (Hung \& Petrick, 2012) terdapat hasil yang berpengaruh negatif antara travel constraints dan niat berkunjung. Namun, pada penelitian Lee et al., (2012) menunjukkan hasil yang berbeda mengenai travel constraints di setiap dimensinya. Dimensi struktural pada travel constraints menunjukkan pengaruh yang negatif terhadap niat berkunjung. Sedangkan untuk dimensi interpersonal dan intrapersonal menunjukkan pengaruh positif terhadap niat berkunjung.

\section{MODEL PENELITIAN}

Berdasarkan variabel yang telah diuraikan, maka kerangka konseptual pada penelitian ini dapat dilihat pada gambar 1 sebagai berikut.

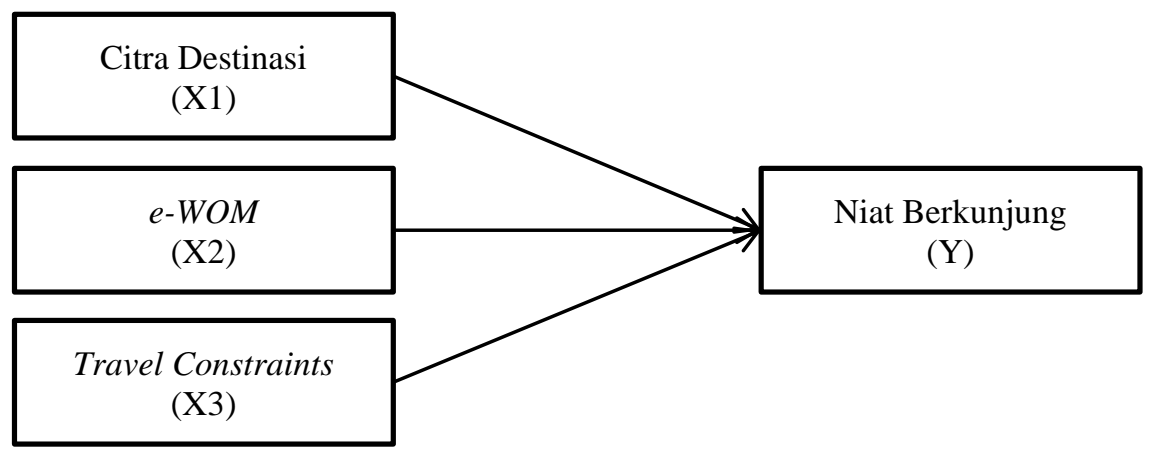

\section{Gambar 1. Kerangka Konseptual}

Sumber : Data diolah peneliti (2020)

\section{Perumusan Hipotesis Penelitian}

Berdasarkan beberapa uraian dan teori yang telah dijelaskan diatas, maka muncul beberapa hipotesis penelitan dalam penelitian ini sebagai berikut:

$\mathrm{H} 1$ : Terdapat pengaruh positif antara citra destinasi terhadap niat berkunjung suatu destinasi wisata.

$\mathrm{H} 2$ : Terdapat pengaruh positif antara $e-W O M$ terhadap niat berkunjung suatu destinasi wisata. 
H3 : Terdapat pengaruh negatif antara travel constraints terhadap niat berkunjung suatu destinasi wisata.

\section{METODE PENELITIAN}

Populasi pada penelitian ini bersifat infinite. Adapun karakteristik responden yaitu berusia 19-50 tahun, dan orang yang belum pernah mengunjungi pantai Kenjeran namun telah meninggalkan komentar pada foto terkait pantai Kenjeran di media sosial Instagram. Jumlah sampel yang digunakan pada penelitian ini sebanyak 200 sampel dengan menggunakan metode non-probability sampling dan teknik judgmental sampling. Penyebaran kuisioner dilakukan secara online dengan menggunakan google form. Pengukuran penelitian ini menggunakan Skala Likert. Teknik analisis data yang digunakan pada penelitian ini adalah analisis regresi linier berganda.

Kemudian pada tabel 2 menjelaskan beberapa pernyataan pengukuran variabel yang digunakan untuk mengukur variabel citra destinasi, e-WOM, travel constraints, dan niat berkunjung. Item tersebut telah digunakan oleh peneliti sebelumnya yang kemudian diadopsi oleh peneliti.

Tabel 2

Item Pengukuran Variabel

\begin{tabular}{|c|c|c|}
\hline Variabel & Peneliti & Item Pernyataan \\
\hline $\begin{array}{l}\text { Citra } \\
\text { Destinasi }\end{array}$ & $\begin{array}{l}\text { Chi et al., } \\
\text { (2018); dan } \\
\text { Prayogo et } \\
\text { al., (2017) }\end{array}$ & $\begin{array}{ll}\text { - } & \text { Destinasi wisata sesuai dengan kepribadian. } \\
\text { - } & \text { Teman-teman akan memikirkan apabila dapat berkunjung. } \\
\text { - } & \text { Citra destinasi ini konsisten dengan citra diri sendiri. } \\
\text { - } & \text { Mengunjungi destinasi ini mencerminkan diri sendiri. } \\
\text { - } & \text { Merasa suka dan tertarik dengan destinasi wisata ini. } \\
\text { - } & \text { Merasa bahagia saat berada pada destinasi wisata ini. } \\
\text { - } & \text { Destinasi ini memiliki pemandangan indah di malam hari. } \\
\text { - } & \text { Merasa nyaman berada pada destinasi wisata ini. }\end{array}$ \\
\hline$e-W O M$ & $\begin{array}{l}\text { Abubakar \& } \\
\text { Ilkan, (2016); } \\
\text { dan Doosti et } \\
\text { al., (2016) }\end{array}$ & $\begin{array}{l}\text { - } \quad \text { Sering membaca ulasan online untuk mengetahui wisata mana } \\
\text { yang dapat menciptakan kesan baik. } \\
\text { - } \quad \text { Sering membaca ulasan online untuk memastikan dapat } \\
\text { memilih wisata yang tepat } \\
\text { - } \quad \text { Sering menggunakan ulasan online untuk memilih wisata yang } \\
\text { menarik. } \\
\text { - } \quad \text { Sering mengumpulkan informasi mengenai ulasan online } \\
\text { sebelum bepergian ke wisata tertentu. } \\
\text { - } \quad \text { Mearasa khawatir jika tidak membaca ulasan online ketika } \\
\text { akan bepergian ke wisata. } \\
\text { - Ulasan online dapat meningkatkan rasa percaya diri ketika } \\
\text { akan mengunjungi suatu destinasi wisata. }\end{array}$ \\
\hline $\begin{array}{l}\text { Travel } \\
\text { Constraints }\end{array}$ & $\begin{array}{l}\text { Khan et al., } \\
(2019)\end{array}$ & $\begin{array}{l}\text { Structural Constraints } \\
\text { - Tidak mempunyai waktu untuk melakukan perjalanan ke } \\
\text { destinasi wisata. }\end{array}$ \\
\hline
\end{tabular}


- Tidak ada informasi tentang wisata yang akan dikunjungi.

- Cuaca tidak menguntungkan di destinasi wisata.

- Ada terlalu banyak lalu lintas menuju destinasi wisata.

- Area yang ingin dikunjungi terlalu jauh.

Interpersonal Constraints

- Tidak ada yang menemani bepergian ke destinasi wisata.

- Keluarga dan teman-teman tidak tertarik berkunjung ke destinasi wisata.

- Tidak menyenangkan bepergian ke destinasi wisata seorang diri.

Intrapersonal Constraints

- $\quad$ Berkunjung ke destinasi wisata tersebut melibatkan terlalu banyak risiko.

- Merasa tidak tertarik dengan kegiatan yang ada di destinasi wisata tersebut.

- Merasa tidak tertarik berkunjung ke destinasi wisata.

Niat Doosti et al., Berencana untuk mengunjungi

Berkunjung (2016); - Mengunjungi wisata di masa depan.

Quintal \& - Mengunjungi wisata tersebut daripada wisata lainnya.

Phau (2015) - Pertimbangan untuk mengunjungi destinasi wisata.

Mengeluarkan upaya

- Mengeluarkan upaya untuk mengunjungi.

Sumber : data diolah peneliti (2020)

Tabel 2 menyebutkan beberapa pernyataan yang digunakan untuk mengukur variabel citra destinasi, $e$-WOM, travel constraints, dan niat berkunjung. Pengukuran variabel tersebut dilakukan dengan cara mengkombinasikan indikator-indikator dari penelitian sebelumnya. Pengukuran pernyataan menggunakan Skala Likert 5 point.

\section{HASIL DAN PEMBAHASAN}

Pada penelitian ini, terlebih dahulu dilakukan pengujian validitas dan reliabilitas angket kepada 30 orang yang bukan termasuk responden untuk sampel penelitian. Angket disebarkan kepada responden berusia 19-50 tahun, dan belum pernah mengunjungi pantai Kenjeran namun telah meninggalkan komentar pada foto terkait pantai Kenjeran di media sosial Instagram. Pernyataan pada angket penelitian ini diukur, kemudian didapat hasil dari uji validitas dan uji reliabilitas. Hasil tersebut menunjukkan bahwa semua item pernyataan menunjukkan hasil yang valid karena nilai Corrected Item - Total Correlation diatas 0,361 sehingga item pernyataan tersebut dapat digunakan sebagai alat ukur variabel citra destinasi, e-WOM, travel constraints, dan niat berkunjung. Kemudian besarnya nilai Cronbach's Alpha untuk pengaruh lebih besar dari 0,70. Sehingga pernyataan-pernyataan pada kuisioner menunjukkan hasil yang reliabel dan dapat digunakan sebagai alat ukur variabel citra destinasi, e-WOM, travel constraints, dan niat berkunjung. 


\section{Uji Asumsi Klasik}

Uji normalitas One-Sample Kolmogorov-Smirnov pada uji asumsi klasik memiliki nilai signifikasi Kolmogorov-Smirnov yaitu asymp sig. (2-tailed) yang lebih besar dari 0,05 yaitu sebesar 0,290. Dengan demikian data yang diperoleh dinyatakan berdistribusi normal. Kemudian uji multikolonieritas yang dapat dilihat dari nilai tolerance dan VIF (Variance Inflation Factor). Adanya multikolineritas ditunjukkan dengan nilai tolerance $\geq 0,01$ atau VIF $\leq 10$ multikolinearitas. Dari hasil uji tersebut, diketahui bahwa nilai tolerance dari variabel citra destinasi yaitu $0.914 \geq 0,01$. Nilai tolerance dari variabel $e$-WOM yaitu $0.986 \geq$ 0,01. Dan nilai tolerance dari variabel travel constraints yaitu $0.914 \geq 0,01$. Dengan hasil tersebut, diketahui bahwa tidak terjadi multikolonieritas antar variabel independen. Begitu juga dengan nilai VIF dari masing-masing variabel independen, untuk nilai VIF dari variabel citra destinasi yaitu $1.094 \leq 10$. Nilai VIF dari variabel $e$-WOM yaitu $1.014 \leq 10$. Dan nilai VIF dari variabel travel constraints yaitu $1.094 \leq 10$. Artinya, tidak terjadi multikolonieritas antar variabel independen. Sehingga dapat diartikan dalam penelitian ini tidak memiliki korelasi yang kuat antar variabel independen, dan model regresi ini dapat ditoleransi. Tahap selanjutnya adalah uji heteroskedastisitas, hasil dari uji Koefisien Korelasi Spearman's pada uji heteroskedastisitas mendapatkan nilai signifikasi pada masing-masing variabel dengan residual lebih besar dari 0,05. Signifikansi pada variabel citra destinasi sebesar 0,935; variabel $e$-WOM sebesar 0,712; dan variabel travel constraints sebesar 0,062. Sehingga dapat diartikan bahwa tidak terjadi masalah heteroskedasitas.

Penyebaran angket dilakukan secara online melalui media sosial Instagram. Angket penelitian disebarkan kepada responden berjumlah 200 orang sesuai dengan batasan yang telah ditentukan sebelumnya. Kemudian didapatkan data karakeristik responden yang telah disajikan pada tabel 3 sebagai berikut.

Tabel 3

Karakteristik Sampel

$\mathbf{N}=\mathbf{2 0 0}$

\begin{tabular}{|c|c|c|c|}
\hline No & Karakteristik Responden & Jumlah & Persentase \\
\hline \multirow[t]{3}{*}{1} & Jenis Kelamin & & \\
\hline & a. Laki-laki & 74 & $37 \%$ \\
\hline & b. Perempuan & 126 & $63 \%$ \\
\hline \multirow[t]{4}{*}{2} & Usia & & \\
\hline & a. 19 - 24 tahun & 122 & $61 \%$ \\
\hline & b. 25 - 35 tahun & 51 & $25.5 \%$ \\
\hline & c. $36-50$ tahun & 27 & $13.5 \%$ \\
\hline \multirow[t]{2}{*}{3} & Tingkat Pendidikan & & \\
\hline & a. SMP Sederajat & 5 & $2.5 \%$ \\
\hline
\end{tabular}


b. SMA/SMK Sederajat
c. Diploma
d. Sarjana

4

4 Pekerjaan
a. Pelajar/Mahasiswa
b. Pegawai Swasta
c. Wirausaha
d. PNS
e. Lainnya

5 Pengeluaran per Bulan
a. < Rp 500.000
b. Rp 500.000 - Rp 2.000 .000
c. Rp 2.000.001 - Rp 3.000.000
d. > Rp 3.000 .000

147

28

20

91

68

19

15

7

39

99

41

21
$73.5 \%$

$14 \%$

$10 \%$

$45.50 \%$

$34 \%$

$9.5 \%$

$7.5 \%$

$3.5 \%$

$19.5 \%$

$49.5 \%$

$20.5 \%$ $10.5 \%$

Sumber : data diolah peneliti (2020)

Tabel 3 menunjukkan dari hasil karakteristik sampel yang didominasi oleh perempuan dengan usia 19-24 tahun, berpendidikan terakhir SMA/SMK Sederajat dengan status pelajar/mahasiswa, serta memiliki pengeluaran per bulan diantara Rp 500.000 - Rp 2.000.000. Hal tersebut berarti bahwa perempuan lebih senang melakukan kegiatan traveling, kemudian melakukan pencarian informasi serta membagikan foto atau video liburan mereka di media sosial seperti Instagram, juga perempuan dalam status pelajar/mahasiswa biasanya mempunyai waktu luang yang lebih banyak dan mereka memanfaatkannya untuk melakukan kegiatan wisata dan salah satunya adalah mengunjungi Pantai Kenjeran.

\section{Hasil Analisis Regresi Linier Berganda}

Hasil dari pengolahan data analisis regresi linier berganda berfungsi untuk mengetahui pengaruh dari variabel citra destinasi, e-WOM dan travel constraints terhadap niat berkunjung calon pengunjung wisata Pantai Kenjeran, didapatkan hasil sebagai berikut :

Tabel 4

Hasil Analisis Regresi Linier Berganda

\begin{tabular}{llcc}
\hline & \multicolumn{2}{c}{ Variabel } & B \\
& \multicolumn{1}{c}{ A } & 11.363 \\
\hline Citra destinasi & $\longrightarrow$ & Niat berkunjung & 0.217 \\
$e$ WOM & $\longrightarrow$ & Niat berkunjung & 0.006 \\
Travel Constraints & $\longrightarrow$ & Niat berkunjung & -0.129 \\
\hline
\end{tabular}

Sumber : Data diolah peneliti (2020)

Pada tabel 4, menunjukkan model persamaan regresi linier berganda yang diperoleh sebagai berikut:

$$
Y=11.363+0,217 \times 1+0,006 \times 2-0,129 \times 3
$$

Keterangan:

$\mathrm{Y} \quad=$ Niat Berkunjung

$\mathrm{X} 1=$ Citra Destinasi 
$\mathrm{X} 2=e-W O M$

$\mathrm{X} 3=$ Travel Constraints

Sehingga dari hasil tersebut dapat diinterpretasikan bahwa terdapat nilai konstanta $(\alpha)$ sebesar 11.363. Artinya, besarnya niat berkunjung pada Pantai Kenjeran sebesar 11.363, maka niat berkunjung ke Pantai Kenjeran tidak akan terjadi tanpa adanya pengaruh citra destinasi, e-WOM, dan travel constraints saat mengunjungi Pantai Kenjeran. Selanjutnya, nilai koefisien citra destinasi (X1) sebesar 0,217. Menunjukkan jika di benak calon pengunjung, citra destinasi mengenai Pantai Kenjeran adalah citra yang baik maka semakin tinggi niat seseorang akan mengunjungi Pantai Kenjeran. Kemudian, nilai koefisien $e$-WOM (X2) sebesar 0,006. Menunjukkan jika $e$-WOM mengenai Pantai Kenjeran memuat informasi positif maka akan semakin tinggi niat calon pengunjung untuk mengunjungi Pantai Kenjeran. Sedangkan, nilai koefisien travel constraints (X3) sebesar $(-0,129)$. Menunjukkan jika semakin tinggi faktor travel constraints yang dirasakan seseorang maka akan menurunkan niat seseorang untuk mengunjungi Pantai Kenjeran. Begitu pula sebaliknya, semakin rendah faktor travel constraints yang dirasakan seseorang maka akan meningkatkan niat seseorang untuk mengunjungi Pantai Kenjeran.

\section{Hasil Uji Hipotesis}

Berdasarkan hasil uji parsial (uji t) pada variabel citra destinasi, e-WOM, travel constraints, dan niat berkunjung, didapatkan hasil sebagai berikut.

Tabel 5

Hasil Uji t dan Signifikan

\begin{tabular}{llcc}
\hline & Variabel & Uji T & Signifikan \\
\cline { 2 - 4 } Citra destinasi & $\longrightarrow$ Niat berkunjung & 6.705 & 0.000 \\
$e$-WOM & Niat berkunjung & 0.100 & 0.920 \\
Travel Constraints & $\longrightarrow$ Niat berkunjung & -3.007 & 0.003 \\
\hline
\end{tabular}

Sumber : Data diolah peneliti (2020)

Tabel 5 menunjukkan hasil uji parsial (uji t) atau nilai t hitung untuk variabel citra destinasi (X1) sebesar 6.705 dengan nilai signifikansi sebesar 0,000 yang lebih kecil dari 0,05 atau 5\%, maka $\mathrm{H}_{0}$ ditolak dan $\mathrm{Ha}$ diterima. Sehingga terdapat pengaruh positif antara citra destinasi terhadap niat berkunjung calon pengunjung Pantai Kenjeran. Kemudian variabel $e$ WOM (X2) menunjukkan nilai t hitung sebesar 0.100 dengan nilai signifikansi sebesar 0,920 yang lebih besar dari 0,05 atau 5\%, maka $\mathrm{H}_{0}$ diterima dan Ha ditolak. Sehingga dapat dikatakan bahwa tidak terdapat pengaruh antara variabel $e$-WOM terhadap niat berkunjung 
calon pengunjung Pantai Kenjeran. Selanjutnya, variabel travel constraints (X3) menunjukkan nilai t hitung sebesar -3.007 dengan nilai signifikansi sebesar 0.003 yang lebih kecil dari 0,05 atau 5\%, maka $\mathrm{H}_{0}$ ditolak dan Ha diterima. Sehingga terdapat pengaruh negatif dan signifikan antara variabel travel constraints terhadap niat berkunjung calon pengunjung Pantai Kenjeran.

\section{Pembahasan}

Citra destinasi didefinisikan sebagai citra dari produk wisata yang terkait dengan destinasi wisata dan fasilitas wisata, yang secara langsung dapat memenuhi kebutuhan wisatawan (Zhang et al., 2017). Lebih lanjut, menurut Jalilvand, (2017) menyatakan bahwa citra destinasi yang unik merupakan inti dari penentuan posisi destinasi karena kemampuannya untuk membedakan destinasi tersebut dari pesaing untuk masuk ke benak konsumen. Selain itu menurut Chi et al., (2018) citra destinasi adalah kumpulan koneksi yang terkait dengan suatu destinasi di benak konsumen. Dalam kaitannya dengan penelitian yang dilakukan di Pantai Kenjeran Kota Surabaya, bahwa citra destinasi merupakan salah satu faktor penting yang dapat mempengaruhi calon wisatawan berkunjung ke destinasi wisata. Citra yang dibangun oleh pengelola wisata Pantai Kenjeran telah mengalami peningkatan dibandingkan dengan sebelumnya seperti perbaikan infrastruktur, memperketat keamanan, serta dengan melihat kebutuhan calon wisatawan akan pemandangan pantai di Kota Surabaya sehingga pengelola wisata menyediakan fasilitas pendukung untuk dapat memunculkan niat calon wisatawan untuk berkunjung ke Pantai Kenjeran. Namun, yang terjadi pada kenyataannya Pantai Kenjeran mengalami penurunan jumlah pengunjung. Hal tersebut yang mendasari pengambilan variabel citra destinasi pada penelitian ini. Hasil penelitian ini menunjukkan bahwa variabel citra destinasi (X1) berpengaruh positif terhadap niat berkunjung (Y). Artinya, semakin meningkat citra destinasi yang melekat di benak calon pengunjung Pantai Kenjeran, maka akan semakin meningkat pula niat berkunjung calon wisatawan Pantai Kenjeran. Hasil tersebut sesuai dengan teori menurut Utama (2017:219) bahwa dalam dunia pariwisata, citra destinasi dapat menggerakkan dan mendorong wisatawan untuk menentukan pilihan destinasi wisatanya. Citra destinasi dari Pantai Kenjeran yang baik akan meningkatkan niat berkunjung dari calon pengunjung Pantai Kenjeran. Hasil penelitian ini juga mendukung penelitian dari Chaulagain et al., (2019) yang menyatakan bahwa citra destinasi secara positif mempengaruhi niat berkunjung. Hasil dari penelitian ini juga selaras dengan penelitian dari Chi et al., (2018) yang menyatakan bahwa 
citra destinasi berpengaruh positif terhadap niat berkunjung.

Menurut Gustiani (2018) e-WOM merupakan komunikasi pemasaran yang berbasis online melalui media sosial internet yang memiliki pesan berisi tentang pernyataan positif atau negatif yang dilakukan oleh konsumen potensial atau konsumen terdahulu. Selanjutnya, $e$-WOM juga berarti sebuah percakapan yang di desain secara online yang memiliki multiple effect, non-hiearchi, horizontal dan multasional (Hasan, 2010:29). Lebih lanjut, menurut penelitian yang dilakukan oleh Jalilvand et al., (2012), mengatakan bahwa informasi atau pesan yang yang terkandung dalam $e$-WOM dapat menjadi referensi bagi konsumen dalam mengevaluasi sebuah produk atau jasa. Dalam kaitannya dengan penelitian yang dilakukan di Pantai Kenjeran Kota Surabaya, bahwa $e-W O M$ yang berupa ulasan atau komentar wisatawan lain di media soaial Instagram dapat menjadi pertimbangan dari calon wisatawan untuk mengunjungi Pantai Kenjeran. Cara yang dilakukan oleh pengelola wisata Pantai Kenjeran untuk menciptakan niat berkunjung ke Pantai Kenjeran dengan cara selalu mempromosikan keindahan Pantai Kenjeran di media sosial Instagram, selalu update kegiatan yang ada di Pantai kenjeran melalui Instagram namun yang terjadi pada kenyataannya Pantai Kenjeran mengalami penurunan jumlah pengunjung. Hal tersebut yang mendasari pengambilan variabel $e$-WOM pada penelitian ini. Hasil pada penelitian ini menunjukkan bahwa variabel $e$ WOM (X2) tidak berpengaruh terhadap niat berkunjung (Y). Artinya semakin meningkat kuantitas $e$-WOM mengenai Pantai Kenjeran maka tidak dapat mempengaruhi niat berkunjung calon pengunjung wisata Pantai Kenjeran. $e$-WOM atau komentar yang terdapat pada foto mengenai Pantai Kenjeran di Instagram tidak mempengaruhi niat berkunjung calon pengunjung karena responden dalam penelitian ini tidak hanya melihat $e$-WOM dari media sosial Instagram saja melainkan dari media sosial lainnya. Penelitian ini tidak selaras dengan penelitian dari Abubakar \& Ilkan, (2016) yang mengatakan bahwa $e$-WOM sangat memengaruhi keputusan konsumen atau wisatawan, karena calon wisatawan menganggap $e$ WOM memuat informasi terbaru, menyenangkan, dan lebih dapat diandalkan daripada informasi yang disediakan oleh penyedia jasa pariwisata. Hasil penelitian ini juga tidak sesuai dengan beberapa penelitian yang dilakukan oleh (Albarq, 2013; Jalilvand, 2017; Doosti et al., 2016; Prayogo dkk, 2017) yang menyatakan bahwa $e$-WOM secara positif mempengaruhi niat berkunjung. Hal ini berarti, semakin baik e-WOM mengenai Pantai Kenjeran maka semakin meningkatkan niat berkunjung calon pengunjung Pantai Kenjeran. Hasil penelitian ini juga tidak sejalan dengan hasil penelitian Abubakar, (2016) yang menyatakan bahwa e-WOM secara negatif mempengaruhi niat berkunjung, karena hasil dari penelitian ini menunjukkan 
bahwa $e-W O M$ mengenai Pantai Kenjeran yang ada di Instagram tidak berpengaruh terhadap niat berkunjung calon wisatawan ke Pantai Kenjeran.

Travel constraints (hambatan perjalanan) didefinisikan sebagai faktor yang dapat menghambat partisipasi dan kenikmatan dalam kegiatan wisata seseorang serta dapat mencegah seseorang untuk bepergian (Hung \& Petrick, 2012). Selain itu, menurut Crompton (1977; dalam Li et al., 2011) menyebutkan terdapat beberapa faktor seperti kurangnya uang, waktu, minat dan dukungan dari keluarga atau kerabat, serta kesehatan yang buruk dapat menjadi kendala utama yang dirasakan seseorang dapat mempengaruhi keputusannya untuk melakukan perjalanan wisata. Dalam kaitannya dengan penelitian yang dilakukan di Pantai Kenjeran Kota Surabaya, bahwa travel constraints atau hambatan perjalanan dapat menjadi pertimbangan penting dari calon wisatawan untuk mengunjungi Pantai Kenjeran. Beberapa langkah yang dilakukan oleh pengelola wisata Pantai Kenjeran dengan cara lebih memperhatikan kebersihan pantai agar wisatawan lebih nyaman dalam berwisata, kemudian meningkatkan fasilitas wisata serta memperketat keamanan di area wisata Pantai Kenjeran dengan memberikan CCTV serta lampu penerangan yang cukup agar dapat meminimalisir tindak kriminalitas. Namun yang terjadi pada kenyataannya Pantai Kenjeran mengalami penurunan jumlah pengunjung. Hal tersebut yang mendasari pengambilan variabel travel constraints pada penelitian ini. Hasil dari penelitian ini menunjukkan bahwa variabel travel constraints (X3) berpengaruh negatif terhadap niat berkunjung (Y). Artinya, semakin meningkat faktor travel constraints yang dapat menghambat calon pengunjung untuk mengunjungi objek wisata Pantai Kenjeran maka akan mengurangi niat berkunjung calon pengunjung Pantai Kenjeran. Hasil penelitian ini sesuai dengan penelitian dari Hung \& Petrick, (2012) yang menyatakan bahwa travel constraints secara negatif mempengaruhi niat berkunjung. Hal ini berarti jika cuaca di sekitar pantai Kenjeran tidak disukai oleh calon pengunjung, maka dapat menurunkan niat berkunjung calon pengunjung tersebut ke Pantai Kenjeran. Khan et al., (2019) dalam penelitiannya juga menyatakan bahwa travel constraints berpengaruh negatif terhadap niat berkunjung wisatawan. Namun, hasil penelitian ini tidak mendukung penelitian dari Lee et al., (2012) yang menunjukkan hasil yang berbeda mengenai travel constraints di setiap dimensinya. Dimensi struktural (faktor eksternal) pada travel constraints menunjukkan pengaruh yang negatif terhadap niat berkunjung. Faktor eksternal dari travel constrains yang terdapat pada Pantai Kenjeran, dapat berupa terlalu banyaknya lampu lalu lintas serta lokasi pantai Kenjeran yang terlalu jauh. Sedangkan untuk dimensi interpersonal dan intrapersonal menunjukkan pengaruh positif terhadap niat 
berkunjung.

\section{SIMPULAN}

Berdasarkan hasil penelitian diatas, dapat disimpulkan bahwa variabel citra destinasi menunjukkan pengaruh positif terhadap niat berkunjung seseorang ke Pantai Kenjeran, kemudian variabel $e$-WOM tidak berpengaruh terhadap niat berkunjung calon wisatawan mengunjungi Pantai Kenjeran, serta variabel travel constraints menunjukkan pengaruh negatif terhadap niat berkunjung calon wisatawan ke Pantai Kenjeran di Kota Surabaya.

\section{IMPLIKASI}

Terdapat implikasi teoritis yang dihasilkan dari penelitian ini. Penelitian ini mendukung kerangka teoritis citra destinasi bahwa variabel citra destinasi berpengaruh positif terhadap niat berkunjung. Begitu juga dengan variabel travel constraints berpengaruh negatif terhadap niat berkunjung. Sedangkan pada penelitian ini tidak mendukung kerangka teoritis $e$-WOM bahwa variabel $e$-WOM tidak memberikan pengaruh apapun terhadap niat berkunjung. Selain itu implikasi terhadap pemasar yang dalam hal ini merupakan penyedia dan pengelola wisata yaitu berdasarkan karakteristik responden, banyak didominasi oleh pengunjung perempuan daripada laki-laki. Hal tersebut membuktikan bahwa perempuan lebih senang melakukan pencarian informasi mengenai tempat wisata yang akan dituju kemudian melakukan kegiatan traveling, serta membagikan foto atau video liburan mereka di media sosial seperti Instagram. Usia didominasi antara 19 - 24 tahun dengan pekerjaan sebagai pelajar/mahasiswa. Hal ini bermanfaat bagi penyedia dan pengelola wisata untuk lebih fokus dalam mengenalkan wisata melalui media sosial kepada calon pengunjung dengan karakteristik tersebut. Kemudian, selain berdasarkan karakteristik responden, penyedia dan pengelola wisata juga disarankan untuk tetap mengenalkan wisata dengan cara baru seperti bekerjasama dengan event atau kegiatan masyarakat yang diminati calon pengunjung dengan karakteristik tersebut. Sehingga menjadikan calon pengunjung dapat dengan mudah menemukan informasi mengenai wisata tersebut dan diharapkan dapat berimbas terhadap niat berkunjung calon pengunjung.

\section{KETERBATASAN DAN SARAN}

Penelitian ini tak lepas dari keterbatasan dan beberapa hambatan sehingga penulis menyarankan beberapa hal yaitu, untuk penelitian selanjutnya disarankan agar melakukan 
penelitian dengan menggunakan variabel lain yang dapat mempengaruhi niat berkunjung seperti motivasi perjalanan, kualitas layanan, kelompok referensi, dan lain-lain. Kemudian untuk penyedia dan pengelola wisata Pantai Kenjeran, dengan melihat rendahnya nilai dari item pernyataan "Saya berencana untuk mengunjungi wisata Pantai Kenjeran dalam waktu dekat" dengan nilai 3,17 maka membuktikan adanya kesadaran masyarakat untuk tidak melakukan kegiatan wisata saat terjadi wabah pandemi Covid-19 di Indonesia. Oleh karena itu, untuk pengelola wisata disarankan agar tetap melakukan komunikasi untuk menjaga hubungan baik dengan wisatawan. Serta penting bagi pengelola untuk mendapatkan kembali kepercayaan wisatawan dan dapat menerima calon wisatawan kembali ketika kondisi pandemi Covid-19 di Indonesia telah membaik. Selanjutnya, untuk penyedia dan pengelola wisata Pantai Kenjeran, dengan melihat respon yang baik dari item pernyataan "Saya akan mempertimbangkan untuk mengunjungi wisata Pantai Kenjeran" dengan nilai 3,90 maka membuktikan bahwa masih adanya ketertarikan calon wisatawan mengunjungi Pantai Kenjeran seusai pandemi Covid-19 ini berakhir. Tentunya, pengelola wisata harus mampu memperhatikan aspek kesehatan dan kebersihan karena hal tersebut akan menjadi aspek yang penting bagi wisatawan dan calon wisatawan Pantai Kenjeran.

\section{DAFTAR PUSTAKA}

Abubakar, A. M., \& Ilkan, M. (2016). Impact of online WOM on destination trust and intention to travel: A medical tourism perspective. Journal of Destination Marketing and Management, 5(3), 192-201.

Albarq, A. N. (2013). Measuring the Impacts of Online Word-of-Mouth on Tourists' Attitude and Intentions to Visit Jordan: An Empirical Study. International Business Research, $7(1), 14-22$.

Cahyanti, M. M., \& Anjaningrum, W. D. (2018). Meningkatkan Niat Berkunjung Pada Generasi Muda Melalui Citra Destinasi Dan Daya Tarik Kampung Wisata. Jurnal Ilmiah Bisnis Dan Ekonomi Asia, 11(2), 35-41.

Chaulagain, S., Wiitala, J., \& Fu, X. (2019). The impact of country image and destination image on US tourists' travel intention. Journal of Destination Marketing and Management, 12(October 2018), 1-11.

Chen, Y. C., Shang, R. A., \& Li, M. J. (2014). The effects of perceived relevance of travel blogs' content on the behavioral intention to visit a tourist destination. Computers in Human Behavior, 30, 787-799. 
Chi, H. K., Huang, K. C., \& Nguyen, H. M. (2018). Elements of destination brand equity and destination familiarity regarding travel intention. Journal of Retailing and Consumer Services, (October), 1-10.

Dinas Kebudayaan dan Pariwisata Provinsi Jawa Timur. (2018). Pariwisata Dalam Angka. Retrieved January 30, 2020, from https://disbudpar.jatimprov.go.id/

Doosti, S., Jalilvand, M. R., Asadi, A., Khazaei Pool, J., \& Mehrani Adl, P. (2016). Analyzing the influence of electronic word of mouth on visit intention: the mediating role of tourists' attitude and city image. International Journal of Tourism Cities, 2(2), $137-148$.

Edward, E. R., \& Balqiah, T. E. (2014). Studi Pengaruh Travel Constraints terhadap Destination Image Wisata Leisure Indonesia: Persepsi dari International Youth Travelers.

Gustiani, M. (2018). Peran Electronic Word Of Mouth Dalam Membangun Citra Destinasi Guna Mempengaruhi Keputusan Berkunjung Wisatawan Ke Suatu Destinasi Pariwisata. Kompetensi, 12, 266-279.

Hahm, J. (Jeannie), \& Severt, K. (2018). Importance of destination marketing on image and familiarity. Journal of Hospitality and Tourism Insights, 1(1), 37-53.

Hasan, A. (2010). Marketing dari Mulut ke Mulut (Pertama). Yogyakarta: Medpress.

Hidayah, N. (2019). Pemasaran Destinasi Pariwisata. Bandung: Penerbit Alfabeta.

Hung, K., \& Petrick, J. F. (2012). Testing the effects of congruity, travel constraints, and selfefficacy on travel intentions: An alternative decision-making model. Tourism Management, 33(4), 855-867.

Jalilvand, A. H. (2017). Comparing face to face and electronic word-of-mouth in destination image formation: the case of Iran. Journal Information Technology \& People, 28(1), $2-$ 33.

Jalilvand, M., Samiei, N., Dini, B., \& Yaghoubi Manzari, P. (2012). Examining the structural relationships of electronic word of mouth, destination image, tourist attitude toward destination and travel intention: An integrated approach. Journal of Destination Marketing and Management, 1(1-2), 134-143.

Kemenparekraf.go.id. (2018). Kementerian Pariwisata dan Ekonomi Kreatif Republik Indonesia. Retrieved November 22, 2019, from http://www.kemenparekraf.go.id/

Khan, Mohammad J., Chelliah, S., Haron, M. S., \& Ahmed, S. (2016). Role of Travel Motivations, Perceived Risks and Travel Constraints on Destination Image and Visit 
Intention in Medical Tourism. 17(February), 11-17.

Khan, Mohammad Jamal, Chelliah, S., Khan, F., \& Amin, S. (2019). Perceived risks, travel constraints and visit intention of young women travelers: the moderating role of travel motivation. 74(3), 721-738.

Lee, B. K., Agarwal, S., \& Kim, H. J. (2012). Influences of travel constraints on the people with disabilities 'intention to travel: An application of Seligman's helplessness theory. Tourism Management, 33(3), 569-579.

Li, M., Zhang, H., Mao, I., Deng, C., Li, M., \& Mao, I. (2011). Segmenting Chinese Outbound Tourists by Perceived Constraints. (January 2015), 37-41.

Lupiyoadi, R. (2013). Manajemen Pemasaran Jasa Berbasis Kompetensi. Jakarta: Salemba Empat.

Mohammed Abubakar, A. (2016). Does eWOM influence destination trust and travel intention: A medical tourism perspective. Economic Research-Ekonomska Istrazivanja, 29(1), 598-611.

Nativeindonesia.com. (2018). Kenjeran Park: Taman Wisata Modern Surabaya yang Hits. Retrieved January 19, 2020, from https://www.nativeindonesia.com/kenjeran-parksurabaya/

Pariwisata Dalam Angka. (2018). Dinas Kebudayaan dan Pariwisata Jawa Timur.

Pratt, M. A., \& Sparks, B. (2014). Predicting Wine Tourism Intention: Destination Image and Self-congruity. Journal of Travel and Tourism Marketing, 31(4), 443-460.

Prayogo, R. R., Ketaren, F. L. S., \& Hati, R. M. (2017). Electronic Word of Mouth, Destination Image, and Satisfaction Toward Visit Intention: an Empirical Study in Malioboro Street, Yogyakarta. 81(Icosop 2016), 209-218.

Quintal, V., \& Phau, I. (2015). The role of movie images and its impact on destination choice. Tourism Review, 70(2), 97-115.

Satyarini, M. N. W., Rahmanita, M., \& Setarnawat, S. (2017). The Influence of Destination Image on Tourist Intention and Decision to Visit Tourist Destination (A Case Study of Pemuteran Village in Buleleng, Bali, Indonesia). 1(1), 81-97.

Surabaya.go.id. (2018). Dinas Kebudayaan dan Pariwisata Kota Surabaya. Retrieved december 05, 2019, from https://surabaya.go.id/dinas-kebudayaan-dan-pariwisata/

Utama, I. B. R. U. (2017). Pemasaran Pariwisata. Yogyakarta: Penerbit ANDI.

Whang, H., Yong, S., \& Ko, E. (2016). Pop culture, destination images, and visit intentions: Theory and research on travel motivations of Chinese and Russian tourists. Journal of 
Business Research, 69(2), 631-641.

Winarta, V. (2017). Pengaruh E-Wom Terhadap Intention Wisata Di Raja Ampat Papua (Theory Of Planned Behavior). Jurnal Ilmiah Mahasiswa Universitas Surabaya, Vol. 6 No., 982-1000.

Yang, J., Yuan, B., \& Hu, P. (2009). Tourism destination image and visit intention: Examining the role of familiarity. Journal of China Tourism Research, 5(2), 174-187.

Zhang, H., Gursoy, D., \& Xu, H. (2017). The Effects of Associative Slogans on Tourists' Attitudes and Travel Intention: The Moderating Effects of Need for Cognition and Familiarity. Journal of Travel Research, 56(2), 206-220. 